\title{
Synthesis and Antiproliferative Activity of Some Quinoline and Oxadiazole Derivatives
}

\author{
Mohamed Jawed Ahsan, ${ }^{1}$ Sunil Shastri, ${ }^{1}$ Rita Yadav, ${ }^{1}$ Mohd. Zaheen Hassan, ${ }^{2}$ \\ Mohammed Afroz Bakht, ${ }^{3}$ Surender Singh Jadav, ${ }^{4}$ and Sabina Yasmin ${ }^{4}$ \\ ${ }^{1}$ Department of Pharmaceutical Chemistry, Maharishi Arvind College of Pharmacy, Ambabari Circle, Jaipur, Rajasthan 302039 , India \\ ${ }^{2}$ School of Chemical Science, University Sains Malaysia, Penang 118 00, Malaysia \\ ${ }^{3}$ Department of Pharmaceutical Chemistry, College of Pharmacy, Prince Sattam Bin Abdulaziz University, \\ P.O. Box 11323, Al-Kharj, Saudi Arabia \\ ${ }^{4}$ Department of Pharmaceutical Chemistry, Birla Institute of Technology, Mesra, Ranchi, Jharkhand 835 215, India
}

Correspondence should be addressed to Mohamed Jawed Ahsan; jawedpharma@gmail.com

Received 21 July 2016; Revised 20 October 2016; Accepted 31 October 2016

Academic Editor: Kirpal Bisht

Copyright ( $) 2016$ Mohamed Jawed Ahsan et al. This is an open access article distributed under the Creative Commons Attribution License, which permits unrestricted use, distribution, and reproduction in any medium, provided the original work is properly cited.

In continuance of our search for newer antiproliferative agents we report herein the synthesis and antiproliferative studies of two series $(\mathbf{5} \mathbf{a}-\mathbf{j}$ and $\mathbf{1 0} \mathbf{a}-\mathbf{c})$ of heterocyclic compounds. All the new compounds were characterized by IR, NMR, and mass spectral data. The antiproliferative activity of 10 compounds (5a-j) was carried out on HeLa (cervix cancer cell line) and MDA-MB-435 (melanoma) and $\mathrm{LC}_{50}$, TGI, and $\mathrm{GI}_{50}$ were calculated, while the antiproliferative activity of 3 compounds (10a-c) was carried out against nine different panels of nearly 60 cell lines (NCI-60) according to the National Cancer Institute (NCI US) Protocol at $10 \mu \mathrm{M}$. 1-(7-Hydroxy-4-methyl-2-oxoquinolin-1(2H)-yl)-3-(4-methoxylphenyl)urea (5j) was found to have antiproliferative activity with $\mathrm{GI}_{50}$ of $35.1 \mu \mathrm{M}$ against HeLa (cervix cancer cell line) and $60.4 \mu \mathrm{M}$ against MDA-MB-435 (melanoma), respectively. The compounds 10a, 10b, and 10c showed antiproliferative activity with comparatively higher selectivity towards HOP-92 (Non-Small Cell Lung Cancer) with percent growth inhibitions (GIs) of 34.14, 35.29, and 31.59, respectively.

\section{Introduction}

Cancer is a genetic disease that is caused by changes to gene that control the way our cell functions. In all types of cancers some of the body's cells begin to divide without stopping and spread into the surrounding tissues. There are more than 100 types of cancer [1]. A total of 1,658,370 new cancer cases and 589,430 cancer deaths are projected to occur in the United States in 2015 [2]. Despite the availability of improved drugs and targeted cancer therapies, it is expected that the new cases of cancer will jump to 19.3 million worldwide by 2025 [3]. The types of cancer treatment include surgery, chemotherapy, radiation therapy, immunotherapy, targeted therapy, and hormonal therapy. The cancer patients are treated either with single therapy or with combinations of more than one therapy depending on the type of cancer's advancement [1]. The therapeutic applications of antiproliferative drugs are restricted due to their toxic potentials, resistance, and genotoxicity [4]. The demand for relatively more effective and safer agents for the treatment of cancer is today's need.

Heterocyclic quinoline nucleus occurs in nature and biologically active substances displaying broad therapeutic applications [5]. Several quinoline analogues were reported as anticancer agents [6-13]. The structure of some of the quinoline anticancer drug is shown in Figure 1 [6]. The biological potential of quinoline inspired us to explore further the quinoline derivatives. The quinoline derivatives showed promising antiproliferative activity against $\mathrm{HeLa}$ (human cervix cancer cell line) and MDA-MB-435 (melanoma) cell lines $[6,7,14]$. Hence we selected HeLa and MDA-MB435 to test the in vitro antiproliferative activity of quinoline derivatives $(\mathbf{5 a}-\mathbf{j})$ reported here in the present investigation. Three-dose response parameters $\left(\mathrm{GI}_{50}, \mathrm{TGI}\right.$, and $\left.\mathrm{LC}_{50}\right)$ were calculated for each of the experimental agents. Similarly the 


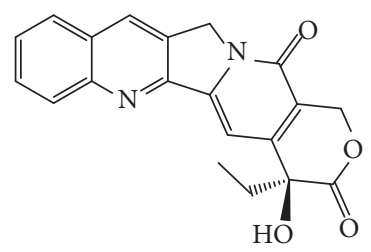

Camptothecin

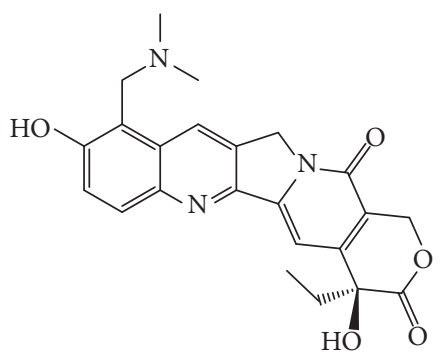

Topotecan

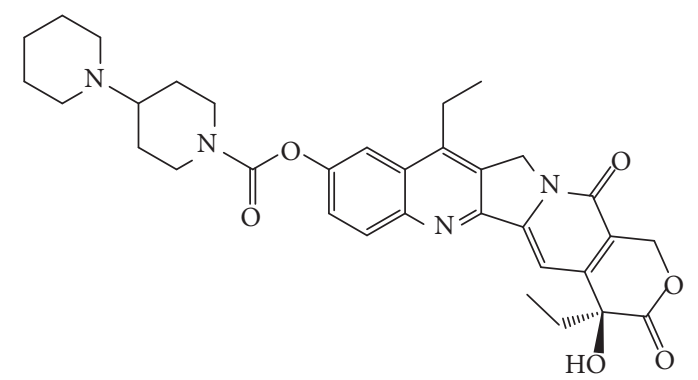

Irinotecan

FIgURE 1: Some of the quinoline containing anticancer drugs.

biological prospects of five member oxadiazoles as anticancer $[15,16]$, antitubercular [17], anticonvulsant [18], antimicrobial [19], anti-HIV [20], and anti-inflammatory [21] inspired us to go on further with the exploration of this moiety. Zibotentan, an endothelin receptor $\mathrm{A}\left(\mathrm{ET}_{\mathrm{A}}\right)$ antagonist, is an anticancer agent which contains 1,3,4-oxadiazole ring [22]. A series of oxadiazoles $(\mathbf{1 0 a}-\mathbf{c})$ were synthesized and evaluated for their antiproliferative activity against 60 cell lines according to the National Cancer Institute (NCI US) Protocol at $10 \mu \mathrm{M}$ drug concentration and percent growth inhibition (GI) was reported.

\section{Materials and Methods}

2.1. General. The chemicals were procured from Merck, Mumbai, and S. D. Fine Chemicals, Mumbai (India). Melting points were determined by open tube capillary method and are uncorrected. The completion of reaction was monitored throughout by thin layer chromatography (TLC) using mobile phase benzene/methanol $(1: 4)$ and cyclohexane/acetone $(1: 4)$ and the spots were located under iodine vapours or UV light. IR spectra were obtained on a Shimadzu $8201 \mathrm{PC}, \mathrm{FT}-\mathrm{IR}$ spectrometer (KBr pellets). ${ }^{1} \mathrm{H}$ NMR spectra were recorded on a Bruker AC $400 \mathrm{MHz}$ spectrometer using TMS as internal standard in $\mathrm{DMSO}_{6}$. Mass spectra were recorded on a Bruker Esquire LCMS using ESI and elemental analyses were performed on Perkin-Elmer 2400 Elemental Analyzer.

2.2. Procedure for the Synthesis of 7-Hydroxy-4-methyl-2Hchromen-2-one (3). A solution of resorcinol (1) (0.1 mol; $11.01 \mathrm{~g})$ in ethyl acetoacetate $(2)(0.1 \mathrm{~mol} ; 13.01 \mathrm{~g} \sim 13 \mathrm{~mL})$ was added slowly into the concentrated $\mathrm{H}_{2} \mathrm{SO}_{4}$ (previously cooled to $5^{\circ} \mathrm{C}$ ) and stirred and the temperature was maintained below $10^{\circ} \mathrm{C}$ for $0.5 \mathrm{~h}$. The reaction mixture was then poured into the crushed ice, filtered, washed, and dried to obtain 7-hydroxy-4-methyl-2H-chromen-2-one (3) Yield 78\%; Mp $192-193^{\circ} \mathrm{C}$ (reported) [23], 194-196 ${ }^{\circ} \mathrm{C}$ (found).

2.3. Procedure for the Synthesis of 1-(7-Hydroxy-4-methyl-2oxoquinolin-1 $(2 \mathrm{H})$-yl) urea/thiourea $(\mathbf{5} \boldsymbol{a}-\boldsymbol{b})$. Equimolar quantity of 7-hydroxy-4-methyl-2H-chromen-2-one (3) $(0.005 \mathrm{~mol}$; $0.88 \mathrm{~g})$ and semicarbazide/thiosemicarbazide $(0.005 \mathrm{~mol})$ was dissolved in ethanol and was refluxed for $4-8 \mathrm{~h}$ at $200^{\circ} \mathrm{C}$ and the reaction mixture was then kept overnight. The reaction was monitored throughout by thin layer chromatography (TLC) using benzene/acetone (1:4) as mobile phase. Finally the product was separated, dried, and recrystallized with methylated spirit.

2.3.1. 1-(7-Hydroxy-4-methyl-2-oxoquinolin-1(2H)-yl)urea (5a). Yield 70\%; Mp 142-144 ${ }^{\circ}$; IR (KBr) cm ${ }^{-1}$ : $3404(\mathrm{OH}), 3202$ (NH), $1685(\mathrm{C}=\mathrm{O}) ;{ }^{1} \mathrm{H}$ NMR (400 MHz; DMSO- $d_{6}$ ) ppm: 2.11 $\left(3 \mathrm{H}, \mathrm{s}, \mathrm{CH}_{3}\right), 5.42\left(2 \mathrm{H}, \mathrm{s}, \mathrm{NH}_{2}\right), 6.31(1 \mathrm{H}, \mathrm{s}, \mathrm{CH}), 6.18(1 \mathrm{H}, \mathrm{s}$, $\operatorname{ArH}), 6.38(1 \mathrm{H}, \mathrm{d}, J=6.1 \mathrm{~Hz}, \operatorname{ArH}), 7.08(1 \mathrm{H}, \mathrm{d}, J=6.0 \mathrm{~Hz}$, ArH), 9.02 (1H, s, CONH) $10.46(1 \mathrm{H}, \mathrm{s}, \mathrm{OH})$; Mass $(\mathrm{m} / z) 233$ $\left(\mathrm{M}^{+}\right)$; Cacld/Anal. [C (56.65) 56.59, H (4.75) 4.78, N (18.02) 18.05].

2.3.2. 1-(7-Hydroxy-4-methyl-2-oxoquinolin-1(2H)-yl)thiourea (5b). Yield 68\%; Mp 112-114 ${ }^{\circ}$; IR (KBr) $\mathrm{cm}^{-1}: 3414(\mathrm{OH})$, $3201(\mathrm{NH}), 1286(\mathrm{C}=\mathrm{S}){ }^{1} \mathrm{H}$ NMR (400 MHz; DMSO- $\left.d_{6}\right) \mathrm{ppm}$ : $2.12\left(3 \mathrm{H}, \mathrm{s}, \mathrm{CH}_{3}\right), 5.40\left(2 \mathrm{H}, \mathrm{s}, \mathrm{NH}_{2}\right), 6.31(1 \mathrm{H}, \mathrm{s}, \mathrm{CH}), 6.28(1 \mathrm{H}$, s, ArH), $6.29(1 \mathrm{H}, \mathrm{d}, J=6.1 \mathrm{~Hz}, \mathrm{ArH}), 7.05(1 \mathrm{H}, \mathrm{d}, J=6.0 \mathrm{~Hz}$, ArH), 8.32 (1H, s, CSNH), $10.41(1 \mathrm{H}, \mathrm{s}, \mathrm{OH})$; Mass $(\mathrm{m} / z) 249$ $\left(\mathrm{M}^{+}\right)$; Cacld/Anal. [C (53.00) 53.05, H (4.45) 4.42, N (16.86) 16.85].

2.4. Procedure for the Synthesis of 1-(7-Hydroxy-4-methyl-2oxoquinolin-1(2H)-yl)-3-substituted Phenyl Urea (5c-j). Equimolar quantity of 7-hydroxy-4-methyl-2H-chromen-2one (3) (0.005 mol; $0.88 \mathrm{~g})$ and substituted phenyl semicarbazide $(0.005 \mathrm{~mol})$ was dissolved in ethanol and was refluxed for $4-8 \mathrm{~h}$ at $200^{\circ} \mathrm{C}$ and the reaction mixture was then kept overnight. Finally the product was separated, dried, and recrystallized with methylated spirit. The reaction was monitored throughout by thin layer chromatography (TLC) using benzene/acetone $(1: 4)$ as mobile phase. The substituted phenyl semicarbazide was synthesized as per the reported method [24].

2.4.1. 1-(7-Hydroxy-4-methyl-2-oxoquinolin-1(2H)-yl)-3-phenylurea (5c). Yield 80\%; Mp 150-152 ${ }^{\circ} \mathrm{C}$; IR (KBr) $\mathrm{cm}^{-1}: 3424$ (OH), $3018(\mathrm{NH}), 1675$ (C=O); ${ }^{1} \mathrm{H}$ NMR (400 MHz; DMSO$\left.d_{6}\right)$ ppm: $2.11\left(3 \mathrm{H}, \mathrm{s}, \mathrm{CH}_{3}\right), 5.90(1 \mathrm{H}, \mathrm{s}, \mathrm{NH}), 6.31(1 \mathrm{H}, \mathrm{s}, \mathrm{CH})$, 6.38-7.05 (8H, m, ArH), $8.39(1 \mathrm{H}, \mathrm{s}, \mathrm{CONH}), 10.49(1 \mathrm{H}, \mathrm{s}$, 
$\mathrm{OH})$; Mass $(\mathrm{m} / z) 309.1\left(\mathrm{M}^{+}\right)$; Cacld/Anal. [C (66.01) 66.04, $\mathrm{H}$ (4.89) 4.90, N (13.58) 13.49].

2.4.2. 1-(7-Hydroxy-4-methyl-2-oxoquinolin-1(2H)-yl)-3-(2,4dimethylphenyl)urea (5d). Yield 70\%; Mp 130-132 ${ }^{\circ} \mathrm{C}$; IR $(\mathrm{KBr}) \mathrm{cm}^{-1}$ : $3434(\mathrm{OH}), 3010(\mathrm{NH}), 1670(\mathrm{C}=\mathrm{O}) ;{ }^{1} \mathrm{H}$ NMR (400 MHz; DMSO-d $)$ ppm: $2.11\left(3 \mathrm{H}, \mathrm{s}, \mathrm{CH}_{3}\right), 2.19(3 \mathrm{H}, \mathrm{s}$, $\left.\mathrm{CH}_{3}\right), 2.34\left(3 \mathrm{H}, \mathrm{s}, \mathrm{CH}_{3}\right), 5.91(1 \mathrm{H}, \mathrm{s}, \mathrm{NH}), 6.10(1 \mathrm{H}, \mathrm{s}, \mathrm{CH})$, 6.68-6.95 (6H, m, ArH), $8.29(1 \mathrm{H}, \mathrm{s}, \mathrm{CONH}), 10.51(1 \mathrm{H}, \mathrm{s}$, $\mathrm{OH})$; Mass $(\mathrm{m} / z) 338.1\left(\mathrm{M}^{+}\right)$; Cacld/Anal. [C (67.64) 67.59, H (5.68) $5.70, \mathrm{~N}(12.46)$ 12.47].

2.4.3.1-(7-Hydroxy-4-methyl-2-oxoquinolin-1(2H)-yl)-3-(2-chlorophenyl)urea (5e). Yield 65\%; Mp 118-120 $\mathrm{C}$; IR $(\mathrm{KBr}) \mathrm{cm}^{-1}$ : $3421(\mathrm{OH}), 3110(\mathrm{NH}), 1679(\mathrm{C}=\mathrm{O}), 695(\mathrm{C}-\mathrm{Cl}) ;{ }^{1} \mathrm{H}$ NMR $\left(400 \mathrm{MHz}\right.$; DMSO- $\left.d_{6}\right)$ ppm: $2.13\left(3 \mathrm{H}, \mathrm{s}, \mathrm{CH}_{3}\right), 5.92(1 \mathrm{H}, \mathrm{s}$, $\mathrm{NH}), 6.33$ (1H, s, CH), 6.28-7.45 (7H, m, ArH), $8.72(1 \mathrm{H}, \mathrm{s}$, CONH), 10.49 (1H, s, OH); ${ }^{13} \mathrm{C}$ NMR (100 MHz; DMSO- $\left.d_{6}\right)$ ppm: 160.7, 158.3, 153.7, 148.8, 141.5, 134.9, 130.7, 129.1, 128.9, $128.1,127.3,125.9,123.5,120.7,113.8,106.6$, 97.5, 15.6; Mass $(\mathrm{m} / z) 343.0\left(\mathrm{M}^{+}\right) 345.1(\mathrm{M}+2)^{+}$; Cacld/Anal. [C (59.40) 59.45, $\mathrm{H}$ (4.10) 4.08, N (12.22) 12.25].

2.4.4. 1-(7-Hydroxy-4-methyl-2-oxoquinolin-1(2H)-yl)-3-(4methylphenyl)urea (5f). Yield 59\%; Mp 134-136 C; IR $(\mathrm{KBr}) \mathrm{cm}^{-1}$ : $3409(\mathrm{OH}), 3112(\mathrm{NH}), 1682(\mathrm{C}=\mathrm{O}) ;{ }^{1} \mathrm{H}$ NMR $\left(400 \mathrm{MHz} ; \mathrm{DMSO}-d_{6}\right)$ ppm: $2.11\left(3 \mathrm{H}, \mathrm{s}, \mathrm{CH}_{3}\right), 2.33(3 \mathrm{H}$, s, $\left.\mathrm{CH}_{3}\right), 5.91(1 \mathrm{H}, \mathrm{s}, \mathrm{NH}), 6.34(1 \mathrm{H}, \mathrm{s}, \mathrm{CH}), 6.18-7.09(7 \mathrm{H}$, $\mathrm{m}, \mathrm{ArH}), 8.91(1 \mathrm{H}, \mathrm{s}, \mathrm{CONH}), 10.52(1 \mathrm{H}, \mathrm{s}, \mathrm{OH}) ;{ }^{13} \mathrm{C} \mathrm{NMR}$ (100 MHz; DMSO- $d_{6}$ ) ppm: 159.9, 158.1, 156.3, 153.0, 147.9., $141.6,128.9,128.1,122.5,120.1,114.9,112.9,105.3,97.9,18,2$, 15.5; Mass $(\mathrm{m} / \mathrm{z}) 323.2\left(\mathrm{M}^{+}\right)$; Cacld/Anal. [C (66.86) 66.82, $\mathrm{H}(5.30) 5.35, \mathrm{~N}(13.00)$ 13.04].

2.4.5. 1-(7-Hydroxy-4-methyl-2-oxoquinolin-1(2H)-yl)-3-(2methylphenyl)urea (5g). Yield 73\%; Mp 140-142 C; IR $(\mathrm{KBr}) \mathrm{cm}^{-1}$ : $3410(\mathrm{OH}), 3108(\mathrm{NH}), 1680(\mathrm{C}=\mathrm{O}) ;{ }^{1} \mathrm{H}$ NMR $\left(400 \mathrm{MHz}\right.$; DMSO- $\left.d_{6}\right)$ ppm: $2.14\left(3 \mathrm{H}, \mathrm{s}, \mathrm{CH}_{3}\right), 2.34(3 \mathrm{H}, \mathrm{s}$, $\left.\mathrm{CH}_{3}\right), 5.90(1 \mathrm{H}, \mathrm{s}, \mathrm{NH}), 6.31(1 \mathrm{H}, \mathrm{s}, \mathrm{CH}), 6.19-7.08(7 \mathrm{H}, \mathrm{m}$, ArH), $8.96(1 \mathrm{H}, \mathrm{s}, \mathrm{CONH}), 10.48(1 \mathrm{H}, \mathrm{s}, \mathrm{OH}) ;$ Mass $(m / z)$ $323.2\left(\mathrm{M}^{+}\right)$; Cacld/Anal. [C (66.86) 66.83, H (5.30) 5.34, N (13.00) 13.03].

2.4.6. 1-(7-Hydroxy-4-methyl-2-oxoquinolin-1(2H)-yl)-3-(4fluorophenyl)urea (5 h). Yield 64\%; Mp 136-138 C; IR (KBr) $\mathrm{cm}^{-1}$ : $3411(\mathrm{OH}), 3108(\mathrm{NH}), 1678(\mathrm{C}=\mathrm{O}), 785(\mathrm{C}-\mathrm{F}) ;{ }^{1} \mathrm{H}$ NMR (400 MHz; DMSO- $\left.d_{6}\right)$ ppm: $2.33\left(3 \mathrm{H}, \mathrm{s}, \mathrm{CH}_{3}\right), 5.90$ (1H, s, NH), 6.35 (1H, s, CH), 6.24-7.07 (7H, m, ArH), 8.92 $(1 \mathrm{H}, \mathrm{s}, \mathrm{CONH}), 10.59(1 \mathrm{H}, \mathrm{s}, \mathrm{OH}) ;{ }^{13} \mathrm{C} \mathrm{NMR}(100 \mathrm{MHz}$; DMSO- $\left.d_{6}\right)$ ppm: $158.9,156.1,153.9,148.7,147.9,141.3,128.9$, $127.1,122.3,120.1,114.9,112.9,106.3,97.9,15.5$; Mass $(m / z)$ $327.3\left(\mathrm{M}^{+}\right), 329.1(\mathrm{M}+2)^{+}$; Cacld/Anal. [C (62.38) 62.35, H (4.31) 4.34, N (12.84) 12.85].

2.4.7. 1-(7-Hydroxy-4-methyl-2-oxoquinolin-1(2H)-yl)-3-(4bromophenyl)urea (5i). Yield 66\%; Mp 126-126 C; IR (KBr) $\mathrm{cm}^{-1}$ : $3411(\mathrm{OH}), 3102(\mathrm{NH}), 1672(\mathrm{C}=\mathrm{O}), 694(\mathrm{C}-\mathrm{Br}) ;{ }^{1} \mathrm{H}$
NMR (400 MHz; DMSO-d $d_{6}$ ppm: $2.31\left(3 \mathrm{H}, \mathrm{s}, \mathrm{CH}_{3}\right), 5.91$ (1H, s, NH), 6.35 (1H, s, CH), 6.28-7.25 (7H, m, ArH), 8.82 $(1 \mathrm{H}, \mathrm{s}, \mathrm{CONH}), 10.54(1 \mathrm{H}, \mathrm{s}, \mathrm{OH})$; Mass $(\mathrm{m} / z) 387.1\left(\mathrm{M}^{+}\right)$, $389.3(\mathrm{M}+2)^{+}$; Cacld/Anal. [C (52.60) 52.63, H (3.63) 3.64, N (10.82) 10.84].

2.4.8. 1-(7-Hydroxy-4-methyl-2-oxoquinolin-1(2H)-yl)-3-(4methoxylphenyl)urea (5j). Yield $72 \%$; Mp $166-168^{\circ} \mathrm{C}$; IR $(\mathrm{KBr}) \mathrm{cm}^{-1}$ : $3401(\mathrm{OH}), 3099(\mathrm{NH}), 1678(\mathrm{C}=\mathrm{O}) ;{ }^{1} \mathrm{H}$ NMR (400 MHz; DMSO- $\left.d_{6}\right)$ ppm: $2.33\left(3 \mathrm{H}, \mathrm{s}, \mathrm{CH}_{3}\right), 3.81(3 \mathrm{H}, \mathrm{s}$, $\left.\mathrm{OCH}_{3}\right), 5.90(1 \mathrm{H}, \mathrm{s}, \mathrm{NH}), 6.34(1 \mathrm{H}, \mathrm{s}, \mathrm{CH}), 6.25-7.09(7 \mathrm{H}$, $\mathrm{m}, \mathrm{ArH}), 8.88(1 \mathrm{H}, \mathrm{s}, \mathrm{CONH}), 10.55(1 \mathrm{H}, \mathrm{s}, \mathrm{OH}) ;{ }^{13} \mathrm{C} \mathrm{NMR}$ $\left(100 \mathrm{MHz}\right.$; DMSO- $\left.d_{6}\right) \mathrm{ppm}: 160.9,158.2,156.4,153.9,148.7$, 141.7, 128.3, 128.1, 122.6, 120.9, 114.5, 113.9, 106.3, 97.9, 56.2, 15.8; Mass $(m / z) 339.3\left(\mathrm{M}^{+}\right)$; Cacld/Anal. [C (63.71) 63.73, H (5.05) 5.08, N (12.38) 12.35].

2.5. Procedure for the Synthesis of Ethyl(pyridine-2-ylamino)acetate (8). 2-Aminopyridine (6) (0.1 mol; 9.41 g) and ethylchloroacetate $(7)(0.2 \mathrm{~mol} ; \sim 24 \mathrm{~mL})$ were taken in a round bottom flask and suspended in $80-100 \mathrm{~mL}$ acetone and $10 \mathrm{~g}$ anhydrous potassium carbonate was added to the mixture. The mixture was refluxed for $24 \mathrm{~h}$ on sand bath with vigorous stirring and then cooled and the excess solvent removed under reduced pressure. The residual mass was triturated with ice water to remove potassium carbonate and extracted with ethylacetate $(3 \times 50 \mathrm{~mL})$ and the ethylacetate layer was washed with $10 \%$ sodium hydroxide solution $(3 \times$ $30 \mathrm{~mL})$ followed by water $(3 \times 30 \mathrm{~mL})$ and then dried over anhydrous sodium sulphate and evaporated to dryness to obtain ethyl(pyridin-2-ylamino)acetate (8) as brown solid. Yield 81\%; Mp 94-96 ${ }^{\circ} \mathrm{C}$ (reported) [25], 90-92 ${ }^{\circ} \mathrm{C}$ (found).

2.6. Procedure for the Synthesis of 2-(Pyridin-2-ylamino)acetohydrazide (9). Ethyl(pyridine-2-ylamino)acetate (8) $(0.075 \mathrm{~mol} ; 12.46 \mathrm{~g})$ and hydrazine hydrate $(0.15 \mathrm{~mol}$; $\sim 7.5 \mathrm{~mL}$ ) were refluxed in ethanol for $16 \mathrm{~h}$ on water bath. The two-third volume of reaction mixture was removed under reduced pressure and then poured into crushed ice to obtain 2-(pyridin-2-ylamino)acetohydrazide (9) as brown solid. Yield 85\%; Mp 100-102 ${ }^{\circ} \mathrm{C}$ (reported) [25], $104^{\circ} \mathrm{C}$ (found).

2.7. General Procedure for the Synthesis of $N-\{[5-A r y l-1,3,4-$ oxadiazol-2-yl]methyl $\}$ Pyridin-2-amine Analogues (10a-c). 2-(Pyridin-2-ylamino)acetohydrazide (9) (0.001 mol; $0.166 \mathrm{~g}$ ) and aromatic aldehydes $(0.001 \mathrm{~mol})$ were refluxed $10-12 \mathrm{~h}$ using $20 \mathrm{~mol} \% \mathrm{NaHSO}_{3}$ and ethanol-water system $(1: 2$, $\mathrm{v} / \mathrm{v})$ solvent [26]. After completion of reaction the excess solvent was removed and the concentrate was poured into the crushed ice filter, washed with water, dried, and recrystallized with absolute ethanol to obtain the final product $N-\{[5-$ aryl/alkyl-1,3,4-oxadiazol-2-yl]methyl $\}$ pyridin-2-amine analogues $(10 \mathbf{a}-\mathbf{c})$. The completion of reaction was monitored throughout by thin layer chromatography (TLC) using mobile phase benzene/methanol (1:4) and cyclohexane/acetone $(1: 4)$ and the spots were located under iodine vapours or UV light. 


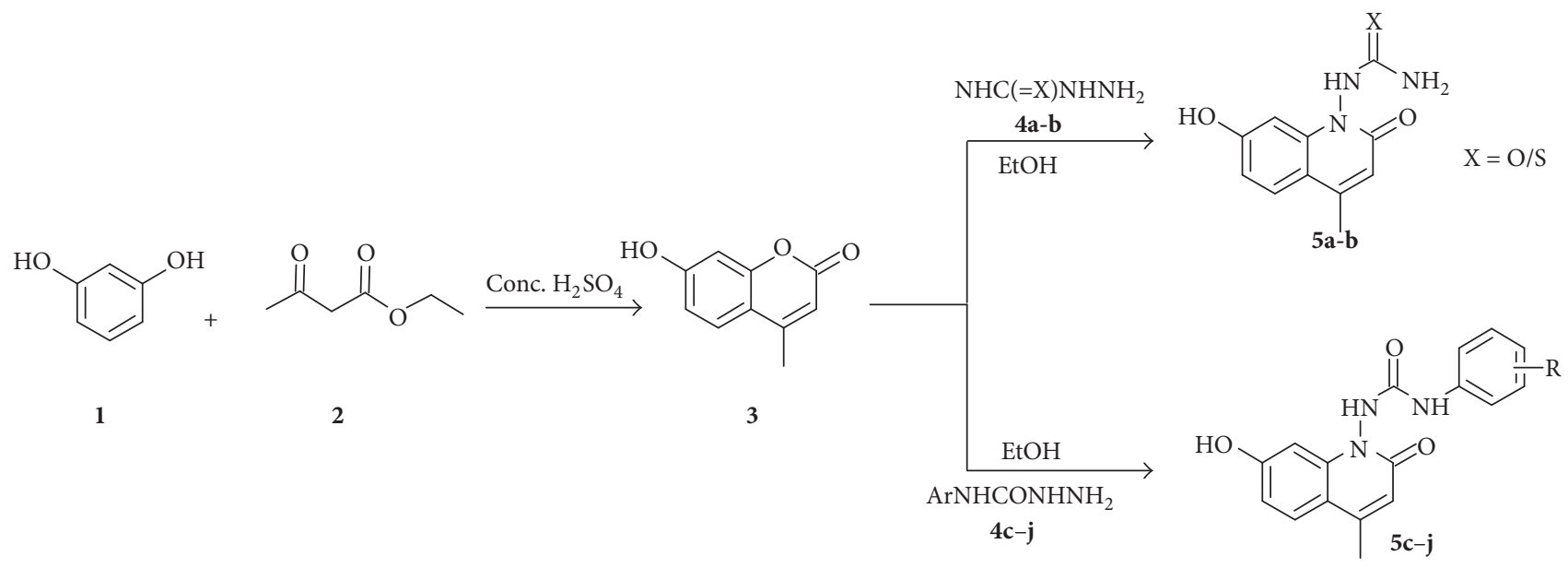

Scheme 1: Protocol for the synthesis of quinoline analogues $(\mathbf{5} \mathbf{a}-\mathbf{j})$.

2.7.1. $N$-\{[5-(4-Chlorophenyl)-1,3,4-oxadiazol-2-yl]methyl $\}$ pyridin-2-amine (10a). Yield 79\%; Mp 198-200 $\mathrm{C}$; IR (KBr) $\mathrm{cm}^{-1}$ : $3192(\mathrm{NH}), 1531(\mathrm{C}=\mathrm{N}), 1153(\mathrm{C}-\mathrm{O}-\mathrm{C}), 764(\mathrm{C}-\mathrm{Cl}) ;{ }^{1} \mathrm{H}$ NMR (400 MHz; DMSO-d $d_{6}$ ppm: $3.32\left(2 \mathrm{H}, \mathrm{s}, \mathrm{CH}_{2}\right), 7.54-$ $7.56(2 \mathrm{H}, \mathrm{d}, J=5.7 \mathrm{~Hz}, \mathrm{ArH}), 7.56-7.58(2 \mathrm{H}, \mathrm{d}, J=6.3 \mathrm{~Hz}$, ArH), 7.87-7.93 (4H, m, pyridine), 8.70 (1H, s, NH); Mass $(\mathrm{m} / z) 286\left(\mathrm{M}^{+}\right), 288(\mathrm{M}+2)^{+}$; Cacld/Anal. [C (58.62) 58.65, $\mathrm{H}$ (3.89) 3.87, N (19.51) 19.54].

2.7.2. $\quad N-\{[5-(4-M e t h o x y p h e n y l)-1,3,4$-oxadiazol-2-yl]methyl\}pyridin-2-amine (10b). Yield 80\%; Mp 150-152 C; IR $(\mathrm{KBr}) \mathrm{cm}^{-1}$ : $3199(\mathrm{NH}), 1541(\mathrm{C}=\mathrm{N}), 1165$ (C-O-C); ${ }^{1} \mathrm{H}$ NMR $\left(400 \mathrm{MHz}\right.$; DMSO- $\left.d_{6}\right)$ ppm: $3.32\left(2 \mathrm{H}, \mathrm{s}, \mathrm{CH}_{2}\right), 3.80(3 \mathrm{H}, \mathrm{s}$, $\left.\mathrm{OCH}_{3}\right), 7.02-7.04(2 \mathrm{H}, \mathrm{d}, J=6.6 \mathrm{~Hz}, \mathrm{ArH}), 7.32-7.34(2 \mathrm{H}$, d, $J=6.1 \mathrm{~Hz}, \mathrm{ArH}), 7.78-7.83(4 \mathrm{H}, \mathrm{m}$, pyridine $), 8.62(1 \mathrm{H}$, s, NH); ${ }^{13} \mathrm{C}$ NMR (100 MHz; DMSO- $\left.d_{6}\right)$ ppm: 162.1, 160.7, 152.3, 148.9, 138.3, 134.5, 128.5, 118.6, 114.8, 113.6, 109.7, 56.2, 51.5; Mass $(m / z) 282\left(\mathrm{M}^{+}\right)$; Cacld/Anal. [C (63.78) 63.82, H (5.03) 5.00, N (19.87) 19.85].

2.7.3. $N$-\{[5-(3,4-Dimethoxyphenyl)-1,3,4-oxadiazol-2-yl $]$ methyl pyridin-2-amine (10c). Yield 82\%; Mp 160-162 C; IR (KBr) $\mathrm{cm}^{-1}$ : $3194(\mathrm{NH}), 1537(\mathrm{C}=\mathrm{N}), 1166(\mathrm{C}-\mathrm{O}-\mathrm{C}) ;{ }^{1} \mathrm{H}$ NMR (400 MHz; DMSO- $\left.d_{6}\right)$ ppm: $3.32\left(2 \mathrm{H}, \mathrm{s}, \mathrm{CH}_{2}\right), 3.80(6 \mathrm{H}, \mathrm{s}$, $\left.\mathrm{OCH}_{3}\right), 7.04-7.06(2 \mathrm{H}, \mathrm{d}, J=6.3 \mathrm{~Hz}, \mathrm{ArH}), 7.34-7.36(2 \mathrm{H}, \mathrm{d}, J$ $=6.3 \mathrm{~Hz}, \mathrm{ArH}), 7.46-7.57$ (4H, m, pyridine), $8.62(1 \mathrm{H}, \mathrm{s}, \mathrm{NH})$; Mass $(m / z) 312\left(\mathrm{M}^{+}\right)$; Cacld/Anal. [C (61.56) 61.53, H (5.13) 5.16, N (17.91) 17.94].

2.8. In Vitro Antiproliferative Activity. Antiproliferative activity of the ten compounds $(\mathbf{5} \mathbf{a}-\mathbf{j})$ was evaluated in two different human cell lines (HeLa and MDA-MB-435) using the sulforhodamine B (SRB) protocol [27, 28], while the antiproliferative screening compounds $(\mathbf{1 0 a}-\mathbf{c})$ were carried out on leukemia, melanoma, lung, colon, CNS, ovarian, renal, prostate, and breast cancers cell lines, nearly 60 in number according to the reported NCI US protocol [29-32].
Three-dose response parameters $\left(\mathrm{GI}_{50}, \mathrm{TGI}\right.$, and $\left.\mathrm{LC}_{50}\right)$ were calculated for each of the experimental agents. Growth inhibition of $50 \%\left(\mathrm{GI}_{50}\right)$ was calculated from $100 \times\left[\left(T_{i}-\right.\right.$ $\left.\left.T_{z}\right) /\left(C-T_{z}\right)\right]=50$, which was the drug concentration resulting in a $50 \%$ reduction in the net protein increase (as measured by sulforhodamine B, SRB staining) in control cells during the drug incubation. The total growth inhibition (TGI) was calculated from $T_{i}=T_{z}$, which was the drug concentration resulting in total growth inhibition and signified the cytostatic effect. The $\mathrm{LC}_{50}$ was calculated from $100 \times\left[\left(T_{i}-\right.\right.$ $\left.\left.T_{z}\right) /\left(C-T_{z}\right)\right]=-50$, which was the drug concentration resulting in a net loss of cells following treatment which indicated the concentration of drug resulting in a $50 \%$ reduction in the measured protein at the end of the drug treatment as compared to that at the beginning.

\section{Results and Discussion}

3.1. Chemistry. The synthetic protocol of quinoline analogues $(5 \mathbf{a}-\mathbf{j})$ is summarized in Scheme 1. In the initial step solution of resorcinol (1) $(0.1 \mathrm{~mol} ; 11.01 \mathrm{~g})$ in ethyl acetoacetate (2) $(0.1 \mathrm{~mol} ; 13.01 \mathrm{~g} \sim 13 \mathrm{~mL})$ was added slowly into the concentrated $\mathrm{H}_{2} \mathrm{SO}_{4}$ (previously cooled to $5^{\circ} \mathrm{C}$ ) and stirred and the temperature was maintained below $10^{\circ} \mathrm{C}$ for $0.5 \mathrm{~h}$ to obtain the intermediate 7-hydroxy-4-methyl- $2 \mathrm{H}$-chromen2-one (3). In the subsequent step an equimolar quantity of 7-hydroxy-4-methyl-2H-chromen-2-one (3) (0.005 mol; $0.88 \mathrm{~g}$ ) and semicarbazide/thiosemicarbazide/substituted phenyl semicarbazide $(0.005 \mathrm{~mol})$ in ethanol $(20 \mathrm{~mL})$ was refluxed for $4-8 \mathrm{~h}$ at $200^{\circ} \mathrm{C}$ to obtain 1-(7-hydroxy-4-methyl2-oxoquinolin-1(2H)-yl)urea/thiourea (5a-b) and 1-(7-hydroxy-4-methyl-2-oxoquinolin-1 $(2 H)$-yl)-3-substituted phenyl urea $(5 \mathbf{c}-\mathbf{j})$. The reaction was monitored throughout by thin layer chromatography (TLC) using benzene/acetone (1:4) as mobile phase. The substituted phenyl semicarbazide used in the final step was synthesized as per the reported method [21]. The yields of the final compounds $(\mathbf{5} \mathbf{a}-\mathbf{j})$ were ranging from $59 \%$ to $80 \%$ after recrystallization with methylated spirit. 2,5-Disubstituted-1,3,4-oxadiazole analogues 


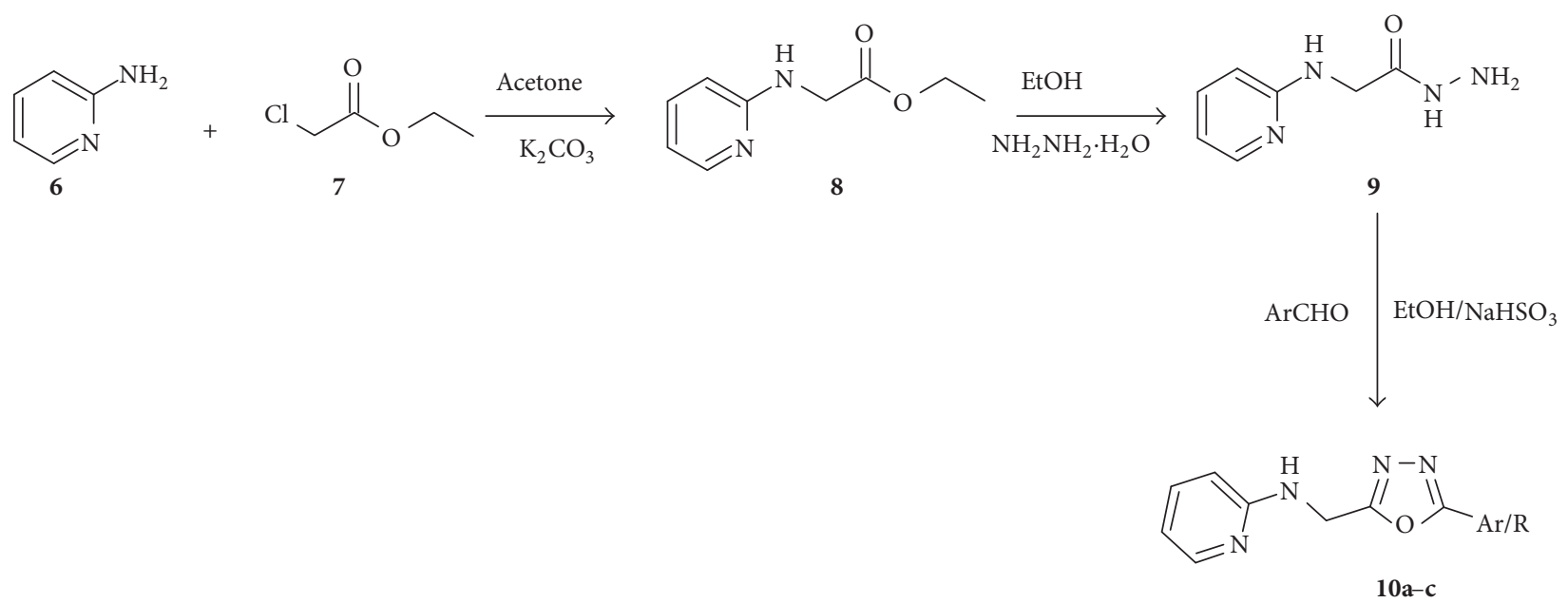

Scheme 2: Protocol for the synthesis of $N$-\{[5-aryl-1,3,4-oxadiazol-2-yl]methyl $\}$ pyridin-2-amine analogues (10a-c).

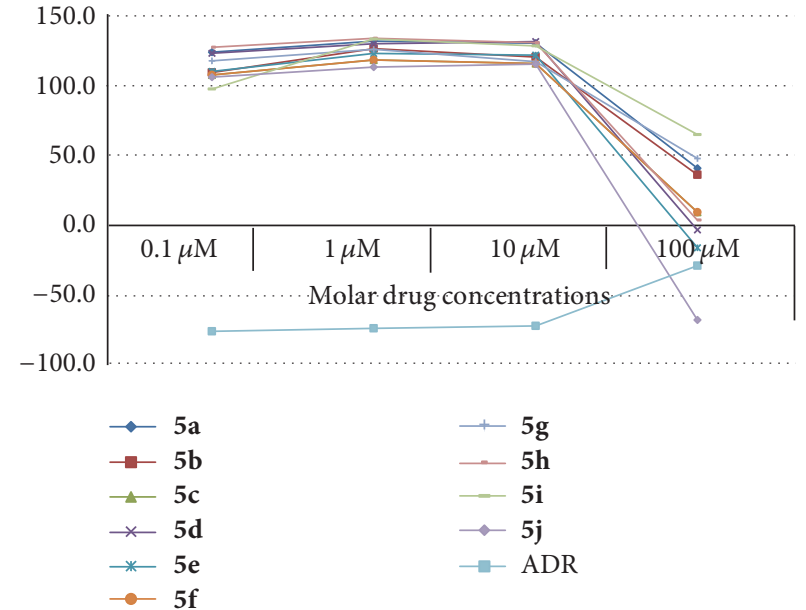

(a)

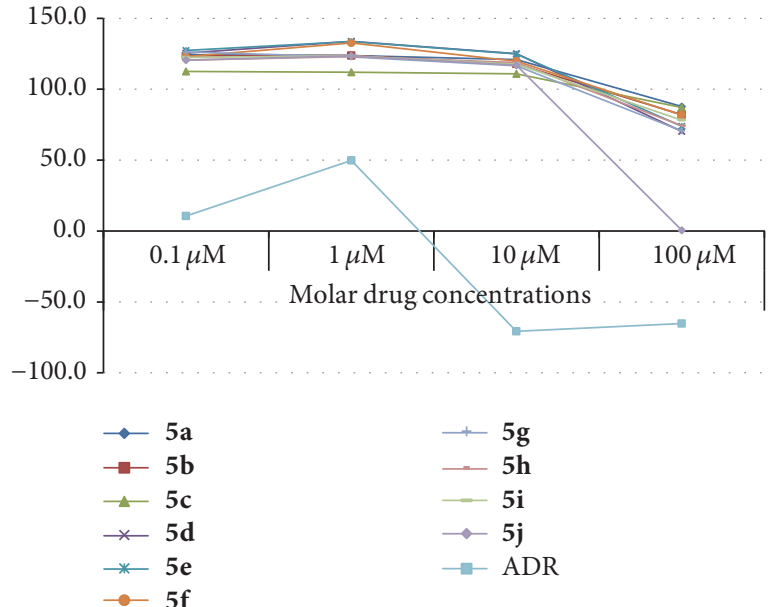

(b)

Figure 2: (a) Growth curve of quinoline analogues (5a-j) HeLa (human cervix cancer cell line) at molar concentrations. (b) Growth curve of quinoline analogues (5a-j) MDA-MB-435 (melanoma) at molar concentrations.

$(\mathbf{1 0 a}-\mathbf{c})$ described in this study were synthesized as per the synthetic protocol summarized in Scheme 2. In the initial step 2-aminopyridine (6) $(0.1 \mathrm{~mol} ; 9.41 \mathrm{~g})$ and ethylchloroacetate (7) $(0.2 \mathrm{~mol} ; \sim 24 \mathrm{~mL})$ were taken in a round bottom flask and suspended in $80-100 \mathrm{~mL}$ acetone and $10 \mathrm{~g}$ anhydrous potassium carbonate was added to the mixture. The mixture was refluxed for $24 \mathrm{~h}$ on sand bath with vigorous stirring to obtain intermediate semisolid ethyl(pyridine-2ylamino)acetate (8). In the subsequent step compound $\mathbf{8}$ was refluxed with hydrazine hydrate in ethanol for $8-12 \mathrm{~h}$ to obtain 2-(pyridine-2-ylamino)acetohydrazide (9) as brown semisolid. In the final step compound 9 was refluxed with aromatic aldehydes for $12-14 \mathrm{~h}$ using $20 \mathrm{~mol} \% \mathrm{NaHSO}_{3}$ and ethanol-water system $(1: 2, \mathrm{v} / \mathrm{v})$ solvent to obtain $N-\{[5-$ aryl-1,3,4-oxadiazol-2-yl]methyl\}pyridin-2-amine analogues $(\mathbf{1 0 a}-\mathbf{c})$. The oxadiazole analogues were synthesized as per the reported method [23]. The yields of the title compounds were ranging between $79 \%$ and $82 \%$ after recrystallization with absolute ethanol. The completion of reaction was monitored throughout by thin layer chromatography (TLC) using mobile phase benzene/acetone (1:4), benzene/methanol (1:4), and cyclohexane/acetone $(1: 4)$. The purity of the synthesized compounds was checked by elemental analysis. Both the analytical and spectral data of the compounds were in full agreement with the proposed structure.

3.2. In Vitro Antiproliferative Activity. 10 compounds (5a-j) were evaluated for antiproliferative activity on HeLa (human cervix cancer cell line) and MDA-MB-435 (melanoma) at four different molar drug concentrations $\left(10^{-7}, 10^{-6}, 10^{-5}\right.$, and $\left.10^{-4} \mathrm{M}\right)$ and the growth percent was recorded. The cytotoxic result was less at first three concentrations but $10^{-4} \mathrm{M}$ concentration produced strong cytotoxicity ranging between -66.9 and 61.2 percent growth against HeLa and 
TABLE 1: $\mathrm{LC}_{50}$, TGI, and $\mathrm{GI}_{50}$ of quinoline analogues (5a-j) against HeLa and MDA-MB-435 cancer cell lines.

\begin{tabular}{|c|c|c|c|c|c|c|}
\hline \multirow{3}{*}{ Compound } & \multicolumn{6}{|c|}{ Drug concentrations calculated from graph $(\mu \mathrm{M})$} \\
\hline & \multicolumn{3}{|c|}{ Human cervix cancer cell line HeLa } & \multicolumn{3}{|c|}{ Melanoma MDA-MB-435 } \\
\hline & $\mathrm{LC}_{50}$ & TGI & $\mathrm{GI}_{50}$ & $\mathrm{LC}_{50}$ & TGI & $\mathrm{GI}_{50}$ \\
\hline $5 \mathrm{a}$ & $>100$ & $>100$ & 87.0 & $>100$ & $>100$ & $>100$ \\
\hline $5 \mathbf{b}$ & $>100$ & $>100$ & 80.6 & $>100$ & $>100$ & $>100$ \\
\hline $5 c$ & $>100$ & $>100$ & 73.20 & $>100$ & $>100$ & $>100$ \\
\hline $5 d$ & $>100$ & 97.28 & 58.9 & $>100$ & 97.28 & $>100$ \\
\hline $5 e$ & $>100$ & 88.17 & 50.6 & $>100$ & 88.17 & $>100$ \\
\hline $5 f$ & $>100$ & $>100$ & 59.9 & $>100$ & $>100$ & $>100$ \\
\hline $5 g$ & $>100$ & $>100$ & 93.0 & $>100$ & $>100$ & $>100$ \\
\hline $5 \mathrm{~h}$ & $>100$ & $>100$ & 62.7 & $>100$ & $>100$ & $>100$ \\
\hline $5 \mathbf{i}$ & $>100$ & $>100$ & $>100$ & $>100$ & $>100$ & $>100$ \\
\hline $5 \mathbf{j}$ & 91.33 & 63.19 & 35.1 & $>100$ & $>100$ & 60.4 \\
\hline $\mathrm{ADR}$ & 54.42 & $<0.1$ & $<0.1$ & 70.6 & 1.7 & $<0.1$ \\
\hline
\end{tabular}

$\mathrm{ADR}=$ adriamycin, positive control compound.

$\mathrm{GI}_{50}$ value of $\leq 10^{-6} \mathrm{M}$ (i.e., $1 \mu$ molar) is considered to demonstrate activity.

between 0.6 and 87.8 percent growth against MDA-MB-435 (Figures 2(a) and 2(b)). The compound 5j showed maximum cytotoxicity with -66.9 and 0.6 percent growths against HeLa and MDA-MB-435, respectively. The cytotoxicity of compound $5 \mathbf{j}$ was found to be higher than the standard drug, adriamycin, at $10^{-4} \mathrm{M}$ concentration against HeLa. Further three parameters $\left(\mathrm{GI}_{50}\right.$, TGI, and $\left.\mathrm{LC}_{50}\right)$ were calculated for all the quinoline derivatives. The $\mathrm{GI}_{50}$ recorded were ranging between 35.1 and $>100 \mu \mathrm{M}$ against HeLa, while only the compound $5 \mathbf{j}$ registered $\mathrm{GI}_{50}$ of $60.4 \mu \mathrm{M}$ against MDA-MB435 and rest of the compounds showed $\mathrm{GI}_{50}$ of $>100 \mu \mathrm{M}$. The $\mathrm{LC}_{50}$ recorded was found to be $>100 \mu \mathrm{M}$ for both the cell lines, except for the compound $5 \mathbf{j}$ which showed $\mathrm{LC}_{50}$ of $91.33 \mu \mathrm{M}$ against HeLa. The compounds $5 \mathbf{j}, \mathbf{5 e}$, and $\mathbf{5 d}$ showed TGI of $63.19,88.17$, and $97.28 \mu \mathrm{M}$, respectively, against HeLa, while compounds $5 \mathbf{e}$ and $\mathbf{5 d}$ showed TGI of 63.19 and 88.17 $\mu \mathrm{M}$, respectively, against MDA-MB-435. The $\mathrm{GI}_{50}$, TGI, and $\mathrm{LC}_{50}$ were recorded for the quinoline derivatives $(\mathbf{5} \mathbf{a}-\mathbf{j})$ and are shown in Table 1 . The value of $\mathrm{GI}_{50}$ was taken into consideration to establish the structure activity relationship (SAR) of the synthesized compounds. The quinoline having 2,4-dimethyl substitution in phenyl ring was found to be more favorable than 4-methyl and 2-methyl substitution, while 2-chloro substitution was found to be more favorable than 4-fluoro and 4-bromo substitutions. The 4-methoxy substitution on phenyl ring showed significant antiproliferative activity. The order of antiproliferative activity followed with substitution on phenyl ring as $4-\mathrm{OCH}_{3}>2-\mathrm{Cl}>2,4-$ $\left(\mathrm{CH}_{3}\right)_{2}>4-\mathrm{CH}_{3}>2-\mathrm{CH}_{3}$. The images of growth control of MDA-MB-435 and HeLa cancer cell lines by some of the quinoline analogues $(\mathbf{5} \mathbf{a}-\mathbf{j})$ and adriamycin are shown in Figures 3(a) and 3(b).

Further since quinoline derivatives were found to inhibit epidermal growth factor receptor tyrosine kinase (EGFR-TK) [33]. A molecular docking study implying epidermal growth factor receptor tyrosine kinase (EGFR-TK) was carried out to observe the binding mode of new quinoline analogues $(\mathbf{5} \mathbf{a}-\mathbf{j})$ on the active site of EGFR-TK. The molecular docking protocol is the same as reported earlier by our research group [34]. Three different binding modes (green, yellow, and grey) were observed by ligands $(\mathbf{5} \mathbf{a}-\mathbf{j})$ as shown in the Figure 4. The binding mode of compounds $5 \mathbf{c}, 5 \mathbf{d}, 5 \mathbf{f}, 5 \mathbf{h}, 5 \mathbf{i}$, and $5 \mathbf{j}$ (green ligands) with the active site of EGFR-TK showed interaction with backbone $\mathrm{H}$-bonding of hydroxyl group with Met793 and side chain H-bonding of NH with Asp855 (5f, $\mathbf{5 i}$, and $\mathbf{5 j}$ ). The binding mode of compounds $\mathbf{5 b}$ (yellow ligands) with the active site of EGFR-TK showed backbone $\mathrm{H}$-bonding of hydroxy group with Met793 and side chain $\mathrm{H}$ bonding of terminal amine with Thr854. The binding mode of compounds $5 \mathbf{a}, 5 \mathbf{e}$, and $\mathbf{5 g}$ (grey ligands) with the active site of EGFR-TK showed backbone H-bonding of NH group with Arg841 and side chain H-bonding of hydroxyl and aryl $\mathrm{NH}$ group with Asp855 and Asn842, respectively, while showing $\pi-\pi$ stacking with Phe723 (compound $5 \mathbf{e}$ ), $\pi$-cationic interaction of substituted phenyl ring with Arg841 (compound $5 \mathrm{~g}$ ). The compound $5 \mathbf{j}$ showed hydrophobic interaction with Met793, Leu792, Ala743, Gly796, Met766, Leu788, Leu777, and Lys745, backbone H-bonding of hydroxyl group with Met793, and side chain H-bonding of $\mathrm{NH}$ with Asp855. The binding mode of interaction with EGFR-TK is given in Figure 5.

Three compounds $(\mathbf{1 0 a}-\mathbf{c})$ were tested for antiproliferative activity on leukemia, melanoma, lung, colon, CNS, ovarian, prostate, and breast cancer cell lines (nearly 60 cell lines) as per the NCI US protocol and carried out at Nation Cancer Institute, USA. The compound $10 \mathrm{~b}$ showed maximum activity with growth percent (GP) of 94.33 followed by compound 10c $(\mathrm{GP}=95.12)$ and 10a $(\mathrm{GP}=96.37)$. The compound 10a showed maximum selectivity towards HOP92, MCF7, SNB-75, T-47D, PC-3, and UO-31 with percent GI of $34.14,21.22,20.52,15.39,14.97$, and 13.57, respectively. The compound 10b showed maximum selectivity towards 


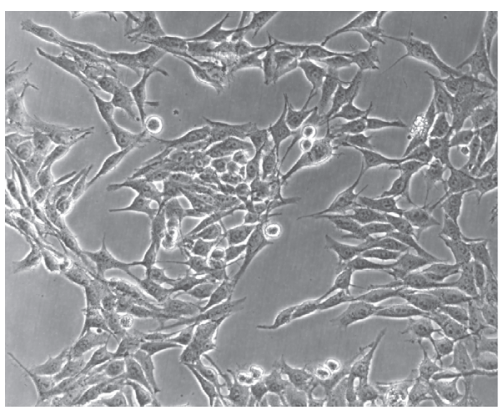

Control

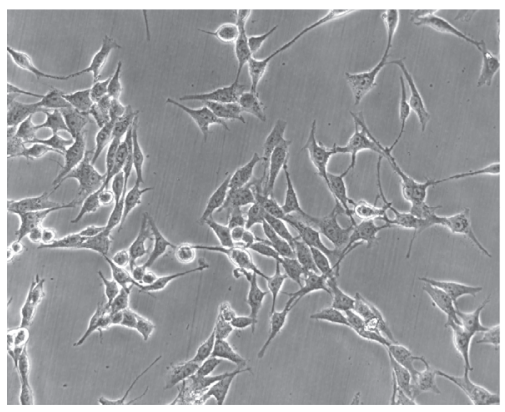

Compound $\mathbf{5 f}\left(\mathrm{GI}_{50}=59.9 \mu \mathrm{M}\right)$

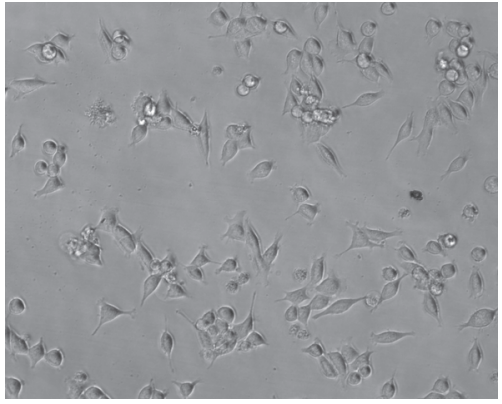

Control

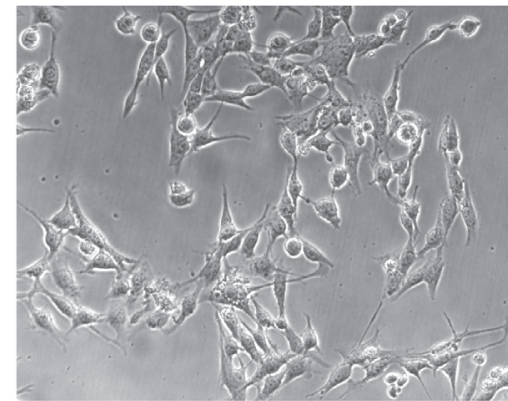

Compound 5d $\left(\mathrm{GI}_{50}=58.9 \mu \mathrm{M}\right)$

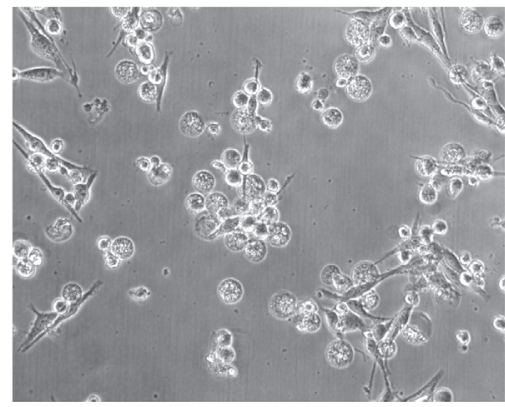

Compound $\mathbf{5 j}\left(\mathrm{GI}_{50}=35.1 \mu \mathrm{M}\right)$

(a)

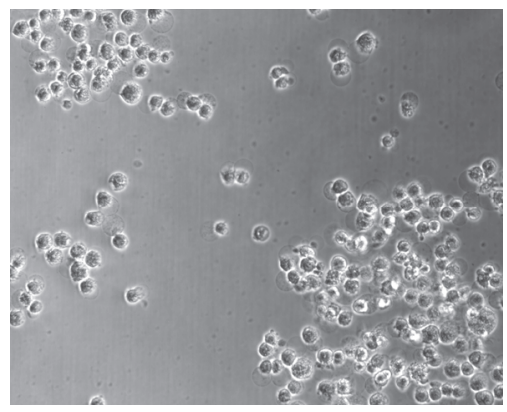

Compound 5j $\left(\mathrm{GI}_{50}=60.4 \mu \mathrm{M}\right)$

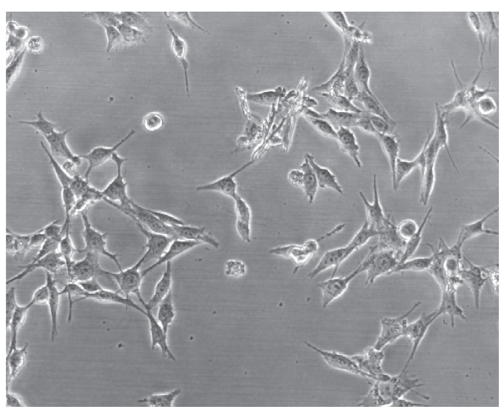

Compound $5 \mathbf{e}\left(\mathrm{GI}_{50}=50.6 \mu \mathrm{M}\right)$

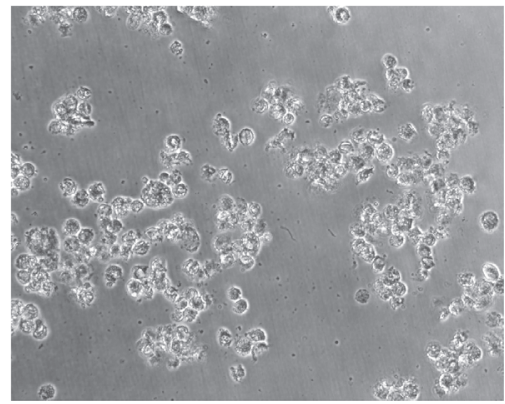

Andriamycin $\left(\mathrm{GI}_{50} \leq 0.1 \mu \mathrm{M}\right)$

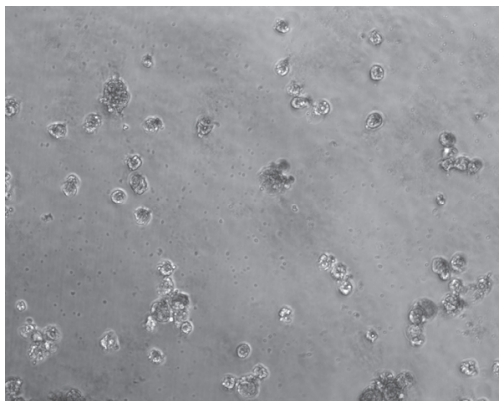

Andriamycin $\left(\mathrm{GI}_{50} \leq 0.1 \mu \mathrm{M}\right)$

(b)

FIGURE 3: (a) Images of growth control of MDA-MB-435 cancer cell line by quinoline (5a-j) and adriamycin. (b) Images of growth control of HeLa cancer cell line by quinoline $(\mathbf{5 a}-\mathbf{j})$ and adriamycin.

HOP-92, CCRF-CEM, HOP-62, PC-3, T-47D, A498, and UO31 with percent GI of 35.29, 24.42, 23.38, 22.27, 22.00, 19.53, and 19.53 , respectively, while compound $10 \mathrm{c}$ showed maximum selectivity towards HOP-92, PC-3, HOP-62, SNB-75, T$47 \mathrm{D}$, and UO-31 with percent GI of 31.59, 25.76, 23.61, 23.04, 21.47 , and 19.48 respectively. The antiproliferative activity is given in Figure 6. The compounds $10 \mathrm{a}, \mathbf{1 0 b}$, and 10c showed maximum selectivity towards HOP-92 (Non-Small Cell Lung Cancer). The maximum percent GI was recorded on HOP-92 by compound 10b. No clear cut structure activity relationship (SAR) was observed with antiproliferative data; however 4-methoxyphenyl substitution on position 5 of oxadiazole ring showed significant result than 3,4-dimethoxyphenyl and 4-chlorophenyl substitution. Earlier we have reported the synthesis of oxadiazole derivatives from pyrimidine-2-amine that showed efficiently binding to the active site of EGFRTK [35]. We can conclude here that EGFR-TK could also be target of the oxadiazoles $(\mathbf{1 0 a}-\mathbf{c})$ reported here in the present investigation.

\section{Conclusion}

All the quinoline $(\mathbf{5} \mathbf{a}-\mathbf{j})$ and oxadiazole $(\mathbf{1 0} \mathbf{a}-\mathbf{c})$ derivatives were synthesized in satisfactory yields. The compound $\mathbf{5 j}$ showed antiproliferative activity among quinoline derivatives with $\mathrm{GI}_{50}$ of $35.1 \mu \mathrm{M}$ against HeLa (cervix cancer cell line) and $60.4 \mu \mathrm{M}$ against MDA-MB-435 (melanoma), respectively. The structure activity relationship established showed that 4-methoxy substitution was found to be more favorable than 2-chloro and 2,4-dimethyl substitution in the phenyl ring. Similarly the compound $\mathbf{1 0 b}$ expressed maximum antiproliferative activity on human cancer cell lines at $10 \mu \mathrm{M}$ concentration. EGFR-TK could be the potential target of the quinoline and oxadiazole derivatives reported here. 


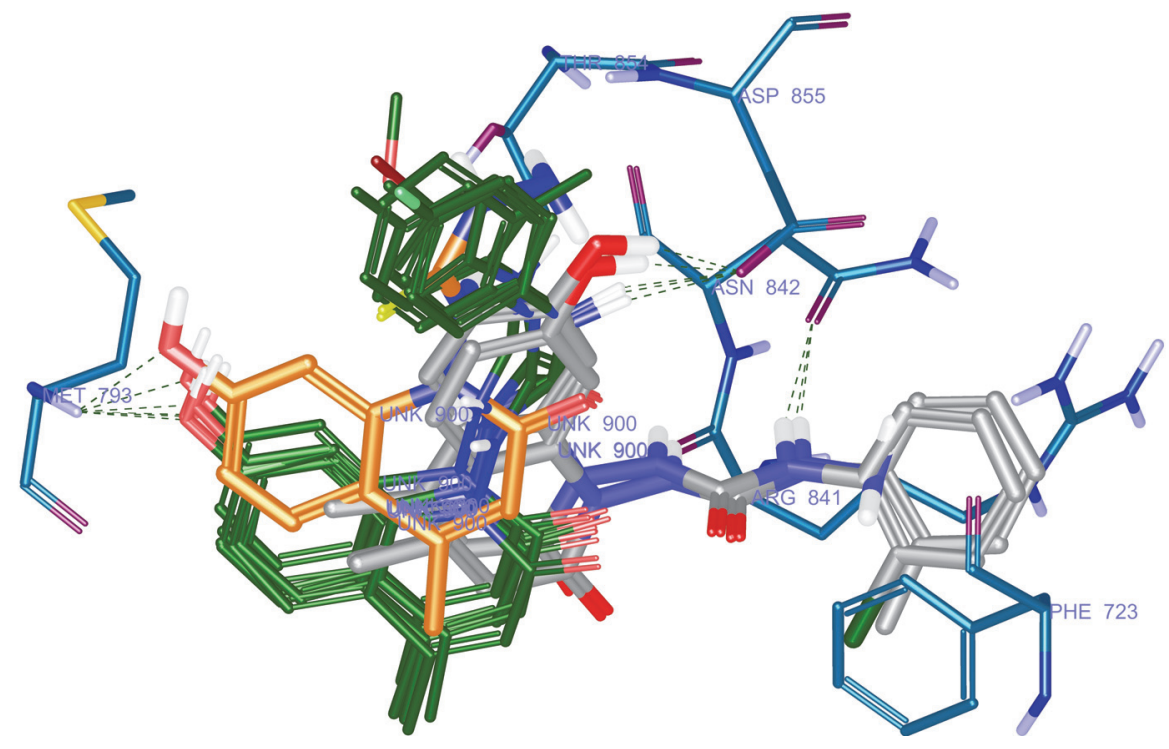

FIGURE 4: The binding modes of quinoline derivatives $(\mathbf{5 a} \mathbf{a} \mathbf{j})$ with the active site of EGFR-TK.

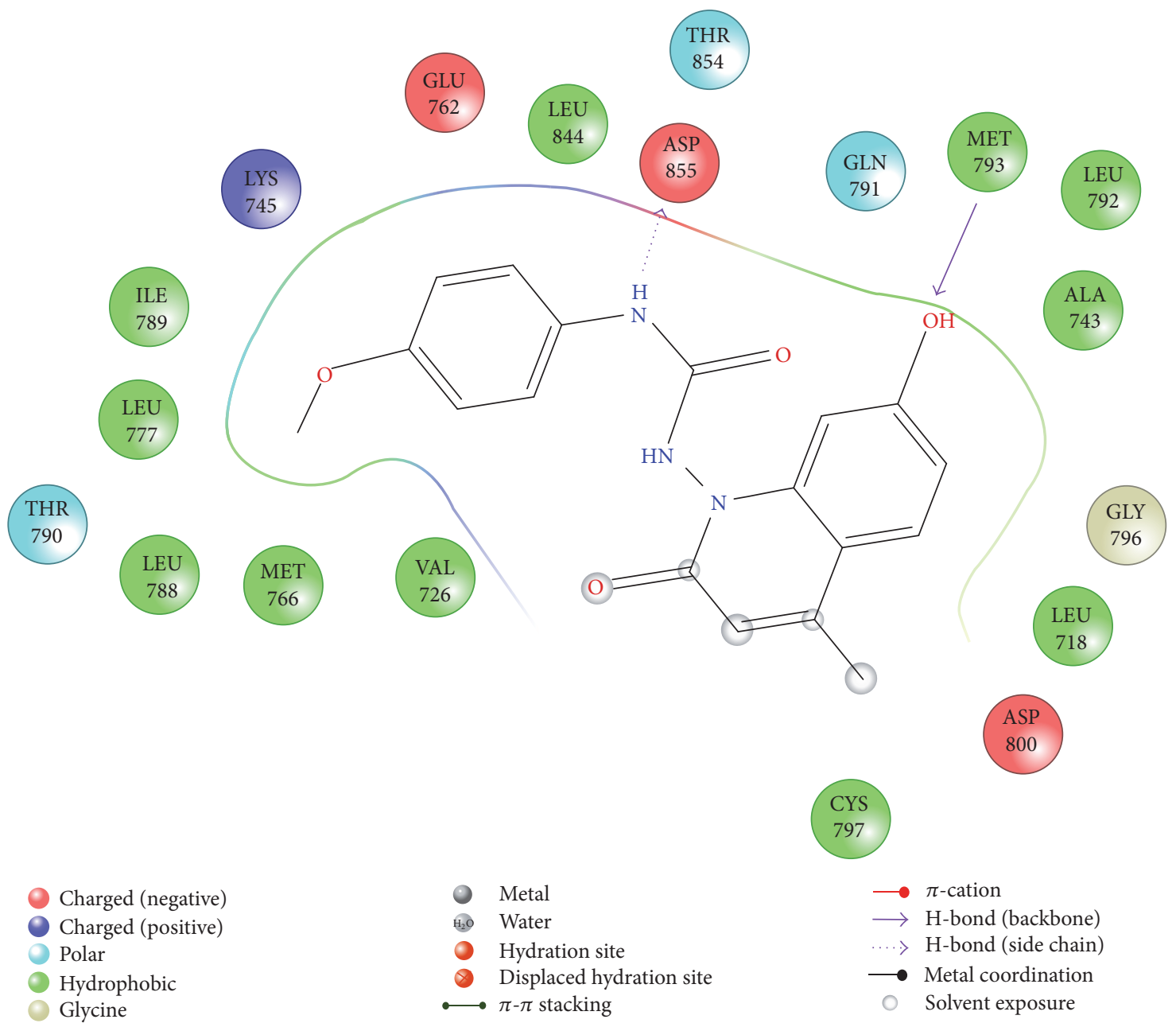

FIGURE 5: The binding modes of quinoline derivative, $\mathbf{5 j}$ with the active site of EGFR-TK. 


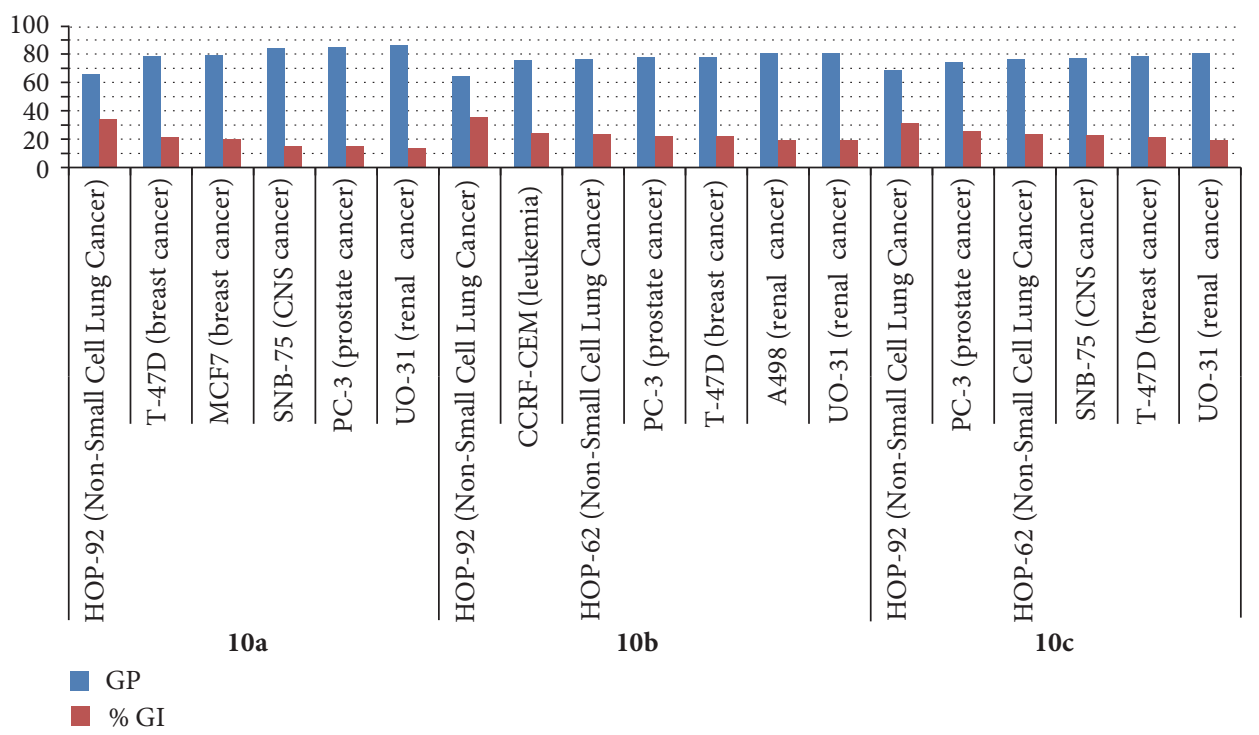

FiguRE 6: In vitro antiproliferative activity of $N$-\{[5-aryl-1,3,4-oxadiazol-2-yl]methyl $\}$ pyridin-2-amine analogues (10a-c) at $10 \mu \mathrm{M}$ drug concentration.

\section{Disclosure}

Part of the work was presented at 1st International Electronic Conference on Medicinal Chemistry, 2015 (doi: 10.3390/ecmc-1-A033 and doi: 10.3390/ecmc-1-A029).

\section{Competing Interests}

The authors confirm that this article's content has no conflict of interests.

\section{Acknowledgments}

Antiproliferative data were provided by Anticancer Drug Screening Facility (ACTREC), Navi Mumbai, India, and National Cancer Institute (NCI US), Bethesda, MD, USA. The authors are grateful for all help provided by Dr. Jyoti Kode, ACTREC, India, Professor Doug Smallwood and Mr. Mohammed Nayel, NCI, USA. The people holding the management of Maharishi Arvind College of Pharmacy, Jaipur, Rajasthan, India, are acknowledged for providing research facilities. They are also grateful to Dr. Reddy Institute of Life Science, Hyderabad, Andhra Pradesh, India, for providing spectral data of synthesized compounds. One of the authors is thankful to DST, Jaipur, for partial financial support (1156/2015).

\section{References}

[1] http://www.cancer.gov/.

[2] R. L. Siegel, K. D. Miller, and A. Jemal, "Cancer statistics, 2015," CA: A Cancer Journal for Clinicians, vol. 65, no. 1, pp. 5-29, 2015.

[3] WHO World Cancer Report 2014, http://www.nydailynews .com/life-style/health/14-million-people-cancer-2012-article1.1545738 .
[4] N. Aydemir and R. Bilaloglu, "Genotoxicity of two anticancer drugs, gemcitabine and topotecan, in mouse bone marrow in vivo," Mutation Research, vol. 537, no. 1, pp. 43-51, 2003.

[5] B. Heiniger, G. Gakhar, K. Prasain, D. H. Hua, and T. A. Nguyen, "Second-generation substituted quinolines as anticancer drugs for breast cancer," Anticancer Research, vol. 30, no. 10, pp. 39273932, 2010.

[6] O. Afzal, S. Kumar, M. R. Haider et al., "A review on anticancer potential of bioactive heterocycles quinoline," European Journal of Medicinal Chemistry, vol. 97, pp. 871-910, 2015.

[7] S. B. Marganakop, R. R. Kamble, T. Taj, and M. Y. Kariduraganvar, "An efficient one-pot cyclization of quinoline thiosemicarbazones to quinolines derivatized with 1,3,4-thiadiazole as anticancer and anti-tubercular agents," Medicinal Chemistry Research, vol. 21, no. 2, pp. 185-191, 2012.

[8] S. B. Marganakop, R. R. Kamble, J. Hoskeri, D. J. Prasad, and G. Y. Meti, "Facile synthesis of novel quinoline derivatives as anticancer agents," Medicinal Chemistry Research, vol. 23, no. 6, pp. 2727-2735, 2014.

[9] E. I. Aly, "Design, synthesis and in vitro cytotoxic activity of new 4-anilino-7-chloro quinoline derivatives targeting EGFR tyrosine kinase," Journal of American Science, vol. 6, pp. 73-83, 2010.

[10] K. Kubo, T. Shimizu, S. I. Ohyama et al., "Novel potent orally active selective VEGFR-2 tyrosine kinase inhibitors: synthesis, structure-activity relationships, and antitumor activities of $\mathrm{N}$ phenyl- $\mathrm{N}^{\prime}$-(4-(4-quinolyloxy)phenyl)ureas," Journal of Medicinal Chemistry, vol. 48, no. 5, pp. 1359-1366, 2005.

[11] C.-H. Tseng, Y.-L. Chen, C.-Y. Hsu et al., "Synthesis and antiproliferative evaluation of 3-phenylquinolinylchalcone derivatives against non-small cell lung cancers and breast cancers," European Journal of Medicinal Chemistry, vol. 59, pp. 274-282, 2013.

[12] M. I. El-Gamal, M. A. Khan, M. S. Abdel-Maksoud, M. M. G. El-Din, and C.-H. Oh, "A new series of diarylamides possessing quinoline nucleus: synthesis, in vitro anticancer activities, and kinase inhibitory effect," European Journal of Medicinal Chemistry, vol. 87, pp. 484-492, 2014. 
[13] S. Chakrabarty, M. S. Croft, M. G. Marko, and G. Moyna, "Synthesis and evaluation as potential anticancer agents of novel tetracyclic indenoquinoline derivatives," Bioorganic \& Medicinal Chemistry, vol. 21, no. 5, pp. 1143-1149, 2013.

[14] C.-T. Chen, M.-H. Hsu, Y.-Y. Cheng et al., "Synthesis and in vitro anticancer activity of 6,7-methylenedioxy (or 5-hydroxy6-methoxy)-2-(substituted selenophenyl)quinolin-4-one analogs," European Journal of Medicinal Chemistry, vol. 46, no. 12, pp. 6046-6056, 2011.

[15] M. Abdel-Aziz, K. A. Metwally, A. M. Gamal-Eldeen, and O. M. Aly, "1,3,4-oxadiazole-2-thione derivatives; novel approach for anticancer and tubulin polymerization inhibitory activities," Anti-Cancer Agents Medicinal Chemistry, vol. 16, no. 2, pp. 269277, 2016.

[16] Salahuddin, M. Shaharyar, A. Majumdar, and M. J. Ahsan, "Synthesis, characterization and anticancer evaluation of 2(naphthalen-1-ylmethyl/naphthalen-2-yloxymethyl)-1-[5-(substitutedpheny)-[1, 3, 4] oxadiazol-2-ylmethyl]-1H-benzimidazole," Arabian Journal of Chemistry, vol. 7, no. 4, pp. 418-424, 2014.

[17] G. Karabanovich, J. Zemanová, T. Smutný et al., "Development of 3,5-dinitrobenzylsulfanyl-1,3,4-oxadiazoles and thiadiazoles as selective antitubercular agents active against replicating and nonreplicating Mycobacterium tuberculosis," Journal of Medicinal Chemistry, vol. 59, no. 6, pp. 2362-2380, 2016.

[18] H. Rajak, B. S. Thakur, A. Singh et al., "Novel limonene and citral based 2,5-disubstituted-1,3,4-oxadiazoles: a natural product coupled approach to semicarbazones for antiepileptic activity," Bioorganic \& Medicinal Chemistry Letters, vol. 23, no. 3, pp. 864-868, 2013.

[19] M. A. Bakht, M. S. Yar, S. G. Abdel-Hamid, S. I. Al Qasoumi, and A. Samad, "Molecular properties prediction, synthesis and antimicrobial activity of some newer oxadiazole derivatives," European Journal of Medicinal Chemistry, vol. 45, no. 12, pp. 5862-5869, 2010.

[20] M. U. Khan, T. Akhtar, N. A. Al-Masoudi, H. StoeckliEvans, and S. Hameed, "Synthesis, crystal structure and antiHIV activity of 2-adamantyl/adamantylmethyl-5-aryl-1,3,4oxadiazoles," Medicinal Chemistry, vol. 8, no. 6, pp. 1190-1197, 2012.

[21] G. C. Ramaprasad, B. Kalluraya, B. Sunil Kumar, and S. Mallya, "Synthesis of new oxadiazole derivatives as anti-inflammatory, analgesic, and antimicrobial agents," Medicinal Chemistry Research, vol. 22, no. 11, pp. 5381-5389, 2013.

[22] https://ncats.nih.gov/files/ZD4054.pdf.

[23] A. Kar, Advanced Practical Medicinal Chemistry, New Age International Publishers, New Delhi, India, 2004.

[24] M. J. Ahsan and J. P. Stables, "Psychomotor seizure test, neurotoxicity and in vitro neuroprotection assay of some semicarbazone analogues," Central Nervous System Agents in Medicinal Chemistry, vol. 13, no. 2, pp. 141-147, 2013.

[25] F. W. Askar, N. K. Abood, and N. A. Jinzell, "Synthesis and characterization of new 2-aminopyridine derivatives," Iraqi National Journal of Chemistry, vol. 52, pp. 453-465, 2013.

[26] J. N. Sangshetti, A. R. Chabukswar, and D. B. Shinde, "Microwave assisted one pot synthesis of some novel 2,5-disubstituted 1,3,4-oxadiazoles as antifungal agents," Bioorganic \& Medicinal Chemistry Letters, vol. 21, no. 1, pp. 444-448, 2011.

[27] V. Vichai and K. Kirtikara, "Sulforhodamine B colorimetric assay for cytotoxicity screening," Nature Protocols, vol. 1, no. 3, pp. 1112-1116, 2006.
[28] V. Prabhakar, R. Balasubramanium, P. Sathe, C. M. Krishna, and A. Juvekar, "In vitro anticancer activity of monosubstituted chalcone derivatives," International Journal of Tumor Therapy, vol. 3, pp. 1-9, 2014.

[29] Development therapeutic program NCI/NIH, 2014, http:// dtp.nci.nih.gov.

[30] A. Monks, D. Scudiero, P. Skehan et al., "Feasibility of a highflux anticancer drug screen using a diverse panel of cultured human tumor cell lines," Journal of the National Cancer Institute, vol. 83, no. 11, pp. 757-766, 1991.

[31] M. R. Body and K. D. Paull, "Some practical considerations and applications of the national cancer institute in vitro anticancer drug discovery screen," Drug Development Research, vol. 34, no. 2, pp. 91-109, 1995.

[32] R. H. Shoemaker, "The NCI60 human tumour cell line anticancer drug screen," Nature Reviews Cancer, vol. 6, no. 10, pp. 813-823, 2006.

[33] M. Chauhan, G. Joshi, H. Kler et al., "Dual inhibitor of epidermal growth factor receptor and topoisomerase II $\alpha$ derived from a quinoline scaffold," RSC Advances, vol. 6, pp. 77717-77734, 2016.

[34] M. J. Ahsan, H. Khalilullah, S. Yasmin, S. S. Jadav, and J. Govindasamy, "Synthesis, characterisation, and in vitro anticancer activity of curcumin analogues bearing pyrazole/pyrimidine ring targeting EGFR tyrosine kinase," BioMed Research International, vol. 2013, Article ID 239354, 14 pages, 2013.

[35] M. J. Ahsan, J. Sharma, S. Bhatia, P. K. Goyal, K. Shankhala, and M. Didel, "Synthesis of 2,5-disubstituted-1,3,4-oxadiazole analogs as novel anticancer and antimicrobial agents," Letters in Drug Design \& Discovery, vol. 11, no. 4, pp. 413-419, 2014. 

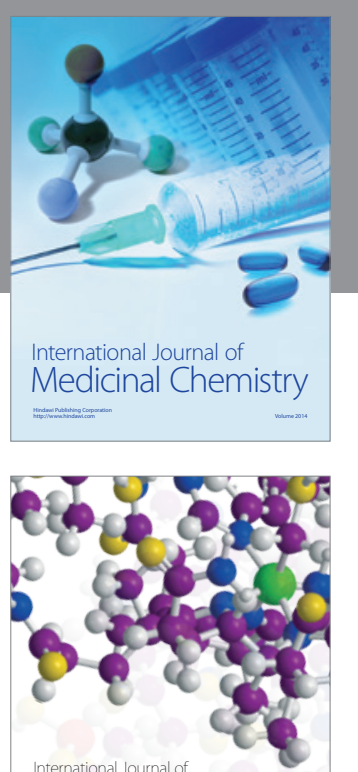

Carbohydrate Chemistry

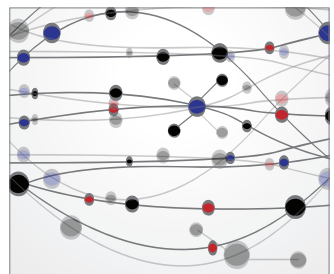

The Scientific World Journal
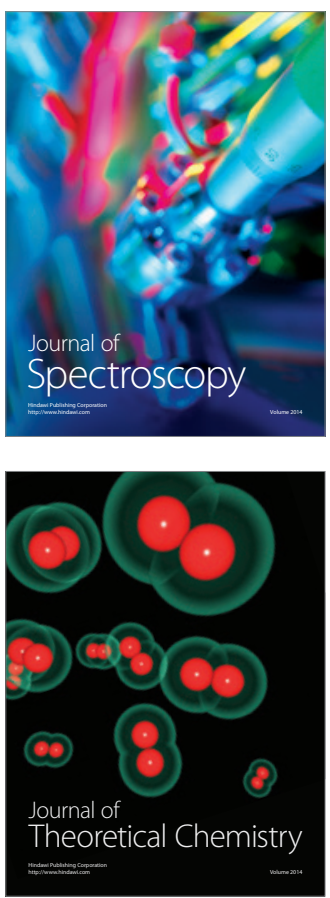
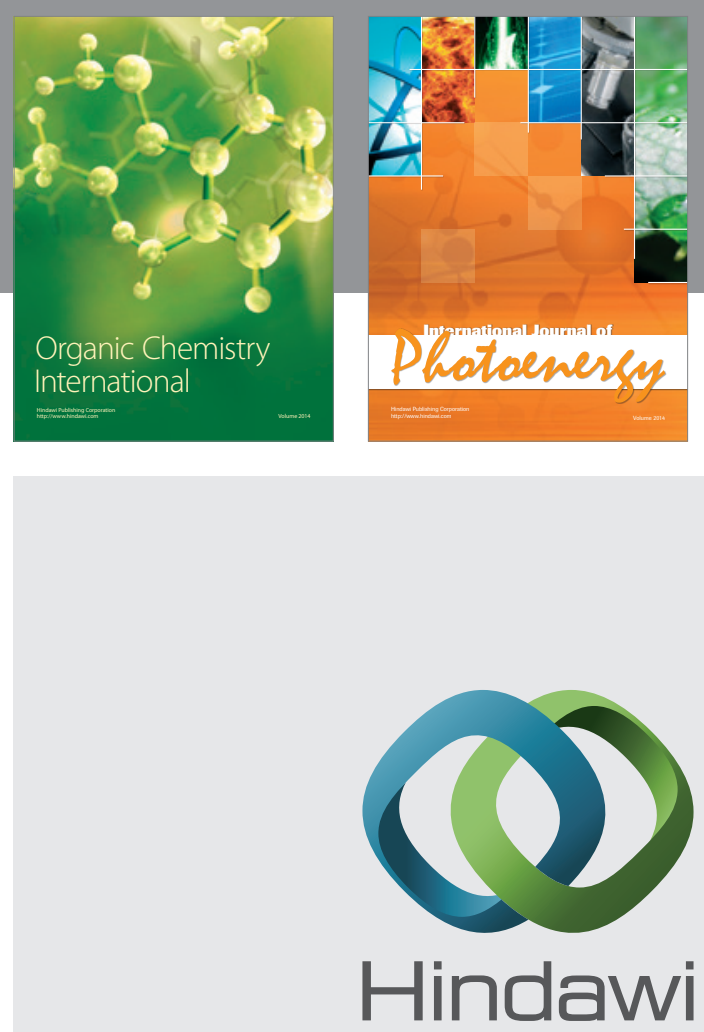

Submit your manuscripts at

http://www.hindawi.com

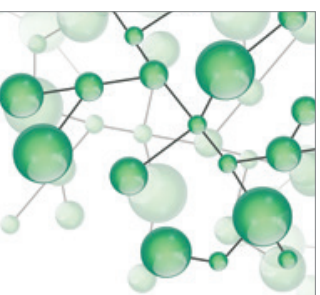

International Journal of

Inorganic Chemistry

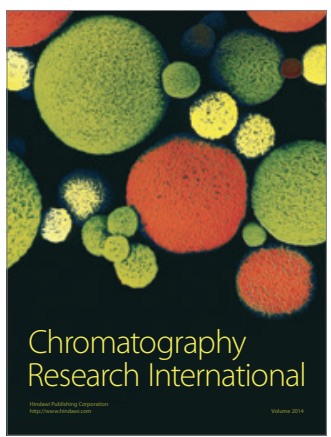

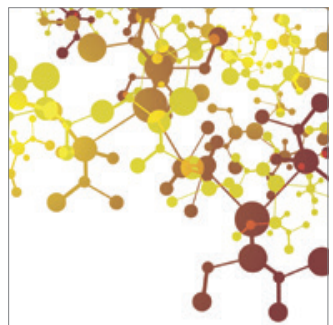

Applied Chemistry
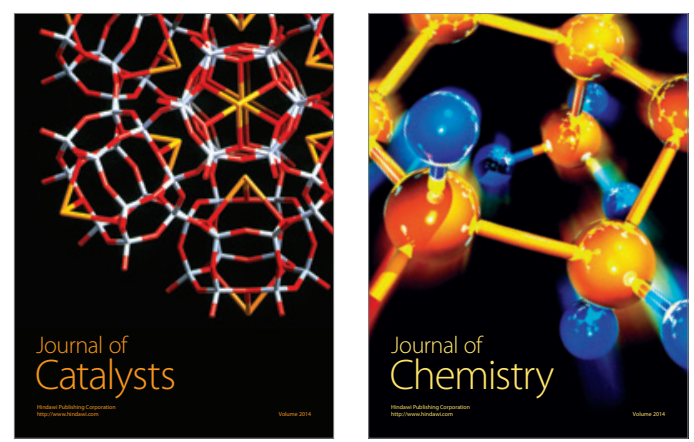
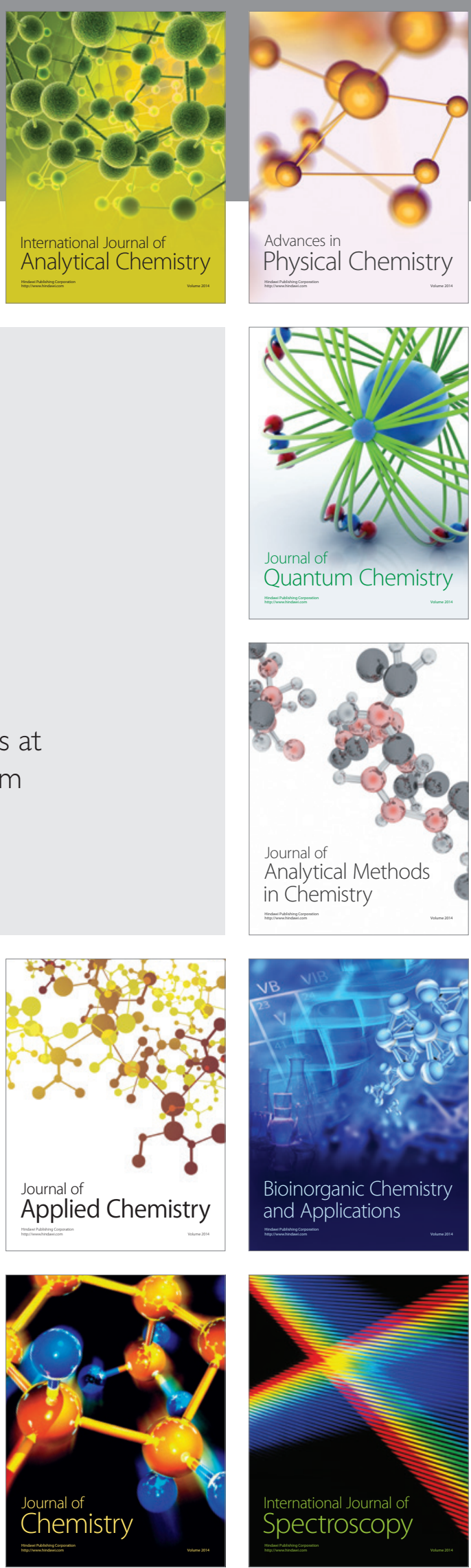